\title{
Occurrence of deoxynivalenol and nivalenol in Korean ginger and the optimal storage conditions for reducing mycotoxins
}

\author{
Mi Jeong Lee, Soo Bin Lim, Jung-Hye Choi, Jeomsoon Kim, Theresa Lee, Ja Yeong Jang* \\ Microbial Safety Division, National Institute of Agricultural Sciences, Rural Development Administration, \\ Wanju 55365, Korea
}

\section{국내산 생강의 데옥시니발레놀과 니발레놀 발생 및 저감화 저장조건}

\author{
이미정 · 임수빈 · 최정혜 · 김점순 · 이데레사 · 장자영* \\ 국립농업과학원 유해생물과
}

\begin{abstract}
Mycotoxin-contaminated food is an important public health issue. The aims of this study were to monitor mycotoxin contamination in Korean ginger and to investigate storage conditions to reduce mycotoxins. A total of 44 ginger samples (27 gingers and 17 ginger powders) were analyzed for contamination with aflatoxin $B_{1}, B_{2}, G_{1}, G_{2}$, ochratoxin A, deoxynivalenol (DON), nivalenol (NIV), and zearalenone (ZEA). Mycotoxin levels were quantified by ultra-performance liquid chromatography after immunoaffinity column clean-up. At least one mycotoxin was present in $37.03 \%$ of the ginger samples $(10 / 27)$ and $41.17 \%$ of the ginger powder samples (7/17). NIV was the most frequently detected mycotoxin in the ginger samples $(37.03 \%, 24.74-263.40 \mu \mathrm{g} / \mathrm{kg})$, while DON $(35.29 \%, 17.62-401.58$ $\mu \mathrm{g} / \mathrm{kg})$, NIV $(29.41 \%, 73.24-439.65 \mu \mathrm{g} / \mathrm{kg})$, and ZEA $(23.53 \%, 5.80-97.84 \mu \mathrm{g} / \mathrm{kg})$ were frequently detected in the ginger powder samples. Aflatoxins and ochratoxin A were not detected in most of the ginger samples. In addition, two or more mycotoxins were found in ginger (25.93\%) and ginger powder samples $(\mathbf{2 9 . 4 1 \% )}$. In the storage experiment, DON and NIV levels in ginger were significantly lower under $13{ }^{\circ} \mathrm{C}$ and $96 \%$ relative humidity than under the other conditions. This is the first report of DON and NIV in Korean ginger samples and the co-occurrence of Fusarium toxins.
\end{abstract}

Keywords : ginger, ginger powder, mycotoxin, storage, storage condition

\section{서 론}

곰팡이독소는 Fusarium 속, Aspergillus 속, 및 Penicillium 속 등 특정 곰팡이에 의해 생성되는 2차 대사산물로서 미량 으로도 인축에 급·만성 독성을 유발할 수 있다(Lee와 Ryu, 2017). 작물의 생산, 수확 및 저장 등의 과정에서 생성된 곰 팡이독소는 전 세계적으로 매년 약 $25-50 \%$ 의 농산물을 감염 시킨다고 알려져 있으며(FAO, 2004), 이들은 물리·화학적
으로 매우 안정하여 가공 및 일반적인 조리과정에 의해 잘 분해되지 않는다. 현재까지 알려진 곰팡이독소는 약 400여 종이나 주로 문제가 되는 것은 아플라톡신, 오크라톡신 $\mathrm{A}$, 푸 모니신, 제랄레논과 트라이코쎄신류 곰팡이독소인 데옥시니 발레놀, 니발레놀, T-2 독소 등이다(Binder 등, 2007).

국제암연구소(International Agency for Research on Cancer, IARC)는 발암성과 관련해 아플라톡신은 발암물질(Group 1), 오크라톡신 A는 인체발암가능물질(Group 2B)로 분류하고,

\footnotetext{
*Corresponding author. E-mail : jabang2@korea.kr, Phone : +82-63-238-3400, Fax : +82-63-238-3840

Received 01 October 2021; Revised 25 October 2021; Accepted 16 November 2021.

Copyright (c) The Korean Society of Food Preservation.

This is an Open Access article distributed under the terms of the Creative Commons Attribution Non-Commercial License (http://creativecommons.org/licenses/by-nc/4.0) which permits unrestricted non-commercial use, distribution, and reproduction in any medium, provided the original work is properly cited.
} 
제랄레논과 데옥시니발레놀은 발암물질로 분류할 수 없는 물 질(Group 3)로 분류하고 있다(IARC, 1993). 트라이코쎄신류 독소와 제랄레논 등은 발암물질로 분류되지는 않지만 구토, 설사, 생식 저하, 면역력 저하, DNA 손상 등을 일으킬 수 있 다(Arnold 등, 1986; Mirocha 등 1971; Pestka, 2010; Wu, 2014). 따라서 우리나라를 비롯한 유럽 연합, 미국 등 전 세 계 여러 국가에서 아플라톡신, 오크라톡신 $\mathrm{A}$, 데옥시니발레 놀, 제랄레논, 푸모니신 등의 독소에 대한 허용기준을 설정하 여 관리하고 있다(MFDS, 2018a). 최근 향신료나 약용식물 등에서 곰팡이독소 오염이 빈번하게 확인됨에 따라(Han 등, 2012; Zinedine 등, 2006) 이들에 대한 안전성 문제가 대두되 고 있다. 따라서 국제적으로 향신료 및 약용식물에 대한 곰팡 이독소 허용 기준치를 설정하거나 그 기준을 확대하였으며 (EPC, 2016; JPC, 2016; USPC, 2017), 우리나라도 최근 아 플라톡신의 기준을 식물성 원료 및 전체 가공식품으로 확대 하여 관리하고 있다(MFDS, 2018a).

생강(Zingiber officinale)은 생강과에 속하는 다년생 초본 식물의 뿌리로, 특유의 매운맛과 향을 가지고 있어, 주로 향 신료로 사용되며 편강, 가루, 차 등으로 가공되어 다양하게 이용되고 있다. 생강은 열대 및 아열대 지역에서 생산되며 인 도, 중국, 나이지리아 등에서 주로 생산되어 유럽과 미국 등 으로 수출된다. 국내 생강은 전북 완주군, 충남 서산시, 경북 안동시에서 주로 생산되며 재배면적은 2019년 기준, 2,324 ha이고 생산량은 24,966 tone으로 추정된다(MAFRA, 2020). 생 강은 진저론(zingerone), 진저롤(gingerols), 쇼가올(shogaols), 파라돌(paradols) 등의 생리활성물질을 생성한다고 보고되어 있으며(Yang 등, 2016), 항산화(Stoilova 등, 2007), 항균(Park 등, 2008), 항당뇨(Akhani 등, 2004), 항염증(Kubra 등, 2012) 등 다양한 생리활성이 보고되어 있다.

생강은 식용 및 약용적 가치로 인해 많은 국가에서 널리 사용되고 있으나 곰팡이독소 오염이 빈번히 보고되어 왔다. 남아프리카에서 여름과 겨울에 판매되는 생강을 수집하여 아 플라톡신의 오염을 조사한 결과 아플라톡신 $\mathrm{B}_{1}$ 은 오염수준 은 0.01-6.04 $\mu \mathrm{g} / \mathrm{kg}$ 이었으나 $86 \%$ 이상의 높은 오염율을 나 타내었다고 보고하였다(Omotayo 등, 2019). 미국에서는 39 개의 생강 시료에 대해 아플라톡신과 오크라톡신 $\mathrm{A}$ 의 오염 을 조사한 결과 26개(66.7\%)에서 아플라톡신이 $1-31 \mu \mathrm{g} / \mathrm{kg}$ 수준으로 검출되었고, 오크라톡신 A는 29개(74.4\%)에서 1-10 $\mu \mathrm{g} / \mathrm{kg}$ 수준으로 오염율과 오염수준이 높음을 보고하였다 (Trucksess 등, 2007). 나이지리아에서는 건기와 우기에 생강 의 곰팡이독소 오염을 조사한 결과 우기에 아플라톡신과 오 크라톡신 $\mathrm{A}$ 의 오염율이 상당히 높았으며 평균 오염농도는 각각 3.13 과 $5.10 \mu \mathrm{g} / \mathrm{kg}$ 이었다고 보고하였다(Lippolis 등, 2017). 이와 같이 생강은 국외에서 발암가능성의 아플라톡신 과 오크라톡신 $\mathrm{A}$ 에 취약한 농산물로 알려져 있으나 국내에
는 관련 연구가 거의 없어 오염실태 파악이 시급하다. 따라서 본 연구에서는 국내에서 생산된 생강 및 생강가루의 곰팡이 독소 오염실태를 조사하였으며, 곰팡이독소 저감을 위한 생 강의 저장조건을 탐색하였다.

\section{재료 및 방법}

\section{시료 수집}

생강의 곰팡이독소 오염도 조사를 위해 농가에서 저장 중 인 생강(2019년산) 22점과 수확기 생강(2020년산) 5점을 대 표 주산지인 충남 서산시와 전북 완주군에서 수집하였다. 수 집된 생강은 수돗물에 깨끗이 씻어 흙 등 이물질을 제거한 다음 얇게 절단하여 $70^{\circ} \mathrm{C}$ 오븐에서 48 시간 동안 건조하였다. 건조된 생강은 분쇄기(CMFP-40000, Hanil, Seoul, Korea)를 이용하여 균질화한 후 $-20^{\circ} \mathrm{C}$ 에 냉동 보관하면서 실험에 사용 하였다. 생강 가루는 열풍건조 또는 동결건조되어 유통되고 있는 지역산 총 17 점(전남, 3점; 전북, 5점; 경남, 1점; 경북, 3점; 충남, 3점; 강원, 2점)의 시료(최소 $150 \mathrm{~g}$ 이상)를 구입 하여 실험에 사용하였다.

\section{저장 실험}

저장 실험을 위한 생강은 2020년도에 두 지역(A, B)에서 수확한 것을 사용하였다. 생강은 지역별로 $20 \mathrm{~kg}$ 두 마대자 루씩 $5^{\circ} \mathrm{C} / 73 \%, 13^{\circ} \mathrm{C} / 96 \%, 14^{\circ} \mathrm{C} / 68 \%$ 저장조건에서 2020 년 11 월 16일부터 2021년 5월 18일까지 6개월간 저장하였다. 이 조건은 각각 냉장 조건 $\left(5^{\circ} \mathrm{C} / 73 \%\right)$, 일부 농가에서 사용하 는 저온창고 조건( $\left.14^{\circ} \mathrm{C} / 68 \%\right)$, 그리고 생강의 품질 유지를 위 한 권장 저장조건( $\left.13^{\circ} \mathrm{C} / 96 \%\right)$ 에 해당한다. 저장고 내의 온도 와 상대습도는 한 시간 간격으로 자동 온 · 습도계 $(\mathrm{HOBO}$ Pro V2 U23-002, Onset Computer Corporation, Bourne, $\mathrm{MA}, \mathrm{USA}$ )를 이용하여 측정하였다. 저장기간 및 저장조건에 따른 생강의 곰팡이독소 오염 조사를 위해 저장 $0,2,4,6$ 개 월 후 시료를 $1 \mathrm{~kg}$ 씩 3회 채집하여 위에서 설명한 것과 같이 세척 후 건조 및 마쇄하여 냉동고( $\left.-20^{\circ} \mathrm{C}\right)$ 에 보관하면서 독소 분석에 사용하였다.

\section{표준물질 및 시약}

실험에 사용한 데옥시니발레놀, 니발레놀, 제랄레논, 아플라 톡신 $\mathrm{B}_{1}, \mathrm{~B}_{2}, \mathrm{G}_{1}, \mathrm{G}_{2}$, 오크라톡신 A는 Biopure(Tulln, Austria) 사의 제품을 구입하여 사용하였다. 아세토니트릴(acetonitrile, $\mathrm{ACN}$ )과 메탄올(methanol, $\mathrm{MeOH}$ )은 high performance liquid chromatography(HPLC)급(Fisher, Darmstadt, Germany)을 사용 하였다. Phosphate buffered saline(PBS)는 Oxoid(Hampshire, $\mathrm{UK}$ )에서 구입하여 사용하였다. Acetic acid는 Merck(Darmstadt, Germany)의 제품을 사용하였다. 탄산수소나트륨 $\left(\mathrm{NaHCO}_{3}\right)$, 
Tween-20, trifluoroacetic acid(TFA), 염화나트륨 $(\mathrm{NaCl})$, 포 름산은 Sigma-Aldrich Co. Ltd.(St. Louis, MO, USA)에서 구 입하여 사용하였다. 3차 증류수는 Millipore (Bedford, MA, USA)의 초순수제조장치를 이용하여 $18.2 \mathrm{M} \Omega$ 이상으로 제 조하여 사용하였다.

\section{시료의 추출 및 정제}

데옥시니발레놀과 니발레놀의 전처리는 Lee 등(2020a)의 방법을 변형하여 수행하였다. 시료 $5 \mathrm{~g}$ 에 $20 \% \mathrm{ACN} 20 \mathrm{~mL}$ 를 가하여 $300 \mathrm{rpm}$ 에서 1시간 동안 진탕 추출(LSI-1005, Daihan Scientific, Seoul, Korea)하였다. 추출액은 2,898 $\times g$ 에서 10 분간 원심분리하여 상층액을 얻었으며, 상층액 $5 \mathrm{~mL}$ 를 취해 1 차 증류수 $20 \mathrm{~mL}$ 와 혼합하여 정제과정에 사용하였 다. DON-NIV 면역친화컬럼(DON-NIV ${ }^{\mathrm{TM}} \mathrm{WB}$, Vicam, MA, USA)에 혼합액 $25 \mathrm{~mL}$ 를 통과시킨 후(2-3 drops/s), 1 차 증류 수 $(10 \mathrm{~mL})$ 로 세척하였다. 주사기를 이용하여 컬럼에 남아 있 는 물을 제거한 후 $\mathrm{MeOH} 2 \mathrm{~mL}$ 를 가하여 컬럼에 남아 있는 독소를 용출하였다. 용출액은 질소 건조 $\left(50^{\circ} \mathrm{C}\right)$ 하여, 이동상 용 액( $1 \mathrm{~mL}$, water:ACN:MeOH, 90:5:5, v/v/v)으로 재용해 한 후 $0.2 \mu \mathrm{m}$ 시린지 필터(PTFE $13 \mathrm{~mm}, \mathrm{RD}$ Tech Research Develompent, Gyeongju, Korea)로 여과 후 ultra performance liquid chromatography (UPLC) 분석을 수행하였다.

제랄레논 분석은 Lee 등(2020b)의 방법을 변형하여 수행하 였다. 시료 $5 \mathrm{~g}$ 에 $\mathrm{NaCl} 1 \mathrm{~g}$ 을 첨가한 후 $75 \% \mathrm{ACN} 20 \mathrm{~mL}$ 를 넣어 1 시간 동안 진탕 추출하였다. 추출액은 $2,898 \times g$ 에서 10 분 동안 원심분리를 통해 상층액 $5 \mathrm{~mL}$ 를 얻었으며 이를 1 차 증류수 $20 \mathrm{~mL}$ 와 혼합하여 정제과정에 사용하였다. 정제용 컬 럼(ZeralaTest $\mathrm{WB})$ 에 혼합액을 통과시킨 다음 $10 \mathrm{~mL}$ 의 증류 수로 세척하였으며 $\mathrm{MeOH} 2 \mathrm{~mL}$ 를 컬럼에 가하여 독소를 용 출하였다. 용출액은 질소 건조한 후 $1 \mathrm{~mL}$ 의 이동상 용액 (Water:ACN:MeOH, 43:35:22, v/v/v)으로 재용해 하였으며 $0.2 \mu \mathrm{m}$ 시린지 필터로 여과한 다음 UPLC 분석을 수행하였다.

아플라톡신의 분석은 Trucksess 등(2006)의 방법을 변형하 여 수행하였다. 시료 $5 \mathrm{~g}$ 에 NaCl $1 \mathrm{~g}$ 과 추출용액(MeOH:1\% Tween-20을 함유한 PBS 용액=8:2, v/v) $20 \mathrm{~mL}$ 를 넣고 300 $\mathrm{rpm}$ 에서 1 시간 동안 진탕 추출하였다. 추출액은 $2,898 \times \mathrm{g}$ 에 서 10 분 동안 원심분리하여 얻어진 상층액 $7 \mathrm{~mL}$ 를 취해 28 $\mathrm{mL}$ 의 $\mathrm{PBS}$ 로 현탁 한 다음 현탁액 $20 \mathrm{~mL}$ 를 취해 정제컬럼 (AflaTest WB)에 주입하였다. 정제 컬럼에 $10 \mathrm{~mL}$ 의 PBS와 증류수를 각각 흘려 불순물을 제거한 다음 $\mathrm{MeOH} 2 \mathrm{~mL}$ 를 흘려 독소를 용출하였다. 용출액은 질소 건조 $\left(50^{\circ} \mathrm{C}\right)$ 후 TFA $0.2 \mathrm{~mL}$ 를 넣어 암조건에서 20 분 동안 반응시켰다. 반응액은 $20 \% \mathrm{ACN} 0.8 \mathrm{~mL}$ 를 가해 재현탁 하였으며, $0.2 \mu \mathrm{m}$ 시린지 필터 후 UPLC 분석을 수행하였다.
오크라톡신 A의 분석은 Truksess 등(2008)의 방법을 변형하 여 수행하였다. 시료 $5 \mathrm{~g}$ 에 $\mathrm{NaCl} 1 \mathrm{~g}$ 과 추출용액(MeOH:0.5\% $\mathrm{NaHCO}_{3}$ 수용액 $\left.=7: 3, \mathrm{v} / \mathrm{v}\right) 20 \mathrm{~mL}$ 를 가하여 $300 \mathrm{rpm}$ 에서 1 시간 동안 추출하였다. 추출액을 $2,898 \times g$ 에서 10 분 동안 원 심분리한 후 상등액 $7 \mathrm{~mL}$ 를 취해 $28 \mathrm{~mL}$ 의 $1 \%$ Tween- 20 을 함유한 PBS 용액으로 희석하였으며, 희석액 $35 \mathrm{~mL}$ 를 면역 친화컬럼(OchraTest WB)에 주입하였다. 정제컬럼에 $10 \mathrm{mM}$ PBS $3 \mathrm{~mL}$ 를 가하여 1차 세척한 다음, $5 \mathrm{~mL}$ 의 물로 2차 세 척하였으며, $2 \mathrm{~mL}$ 의 $\mathrm{MeOH}$ 을 주입하여 독소를 용출하였다. 용출액은 질소 건조 $\left(50^{\circ} \mathrm{C}\right)$ 후 $1 \mathrm{~mL}$ 의 이동상 $(1 \%$ acetic acid 가 들어 있는 water: $\mathrm{ACN}=5: 5, \mathrm{v} / \mathrm{v})$ 으로 재용해한 다음 0.2 $\mu \mathrm{m}$ 시린지 필터 후 UPLC 분석을 수행하였다.

\section{HPLC 분석조건}

데옥시니발레놀, 니발레놀, 제랄레논, 아플라톡신 $\mathrm{B}_{1}, \mathrm{~B}_{2}$, $\mathrm{G}_{1}, \mathrm{G}_{2}$, 오크라톡신 A는 UPLC(Waters Acquity UPLC ${ }^{\circledR} \mathrm{H}$ Class, Waters Corp., MA, USA)를 사용하여 정량 및 정성 분석되었다. 분석 컬럼은 Xselect $\mathrm{CSH} \mathrm{C}_{18}, 1.7 \mu \mathrm{m}, 2.1 \times 100$ $\mathrm{mm}$ (Waters Corp., MA, USA)를 사용하였고, 유속 0.3 $\mathrm{mL} / \mathrm{min}$, 시료 주입량 $10 \mu \mathrm{L}$, 분석 시간 10 분의 등용매조건 (isocratic)으로 분석하였다. 데옥시니발레놀과 니발레놀의 검 출은 water: $\mathrm{ACN}: \mathrm{MeOH}(90: 5: 5, \mathrm{v} / \mathrm{v} / \mathrm{v})$ 이동상과 흡광검출기 (diode array detector) 파장 $218 \mathrm{~nm}$ 를 사용하여 분석을 수행 하였다. 제랄레논 분석용 이동상은 water:ACN:MeOH(43: $35: 22, \mathrm{v} / \mathrm{v} / \mathrm{v}$ )이었고, 형광검출기(fluorescence detector) 파장 $\mathrm{Ex}=274 \mathrm{~nm}, \mathrm{Em}=440 \mathrm{~nm}$ 로 검출하였다. 아플라톡신 분석용 이동상은 water:ACN:MeOH(20:65:15, v/v/v)이었고, 형광검출 기 파장 $\mathrm{Ex}=360 \mathrm{~nm}, \mathrm{Em}=440 \mathrm{~nm}$ 를 사용하여 분석을 수행하였 다. 오크라톡신 A 분석을 위한 이동상은 $1 \%$ acetic acid를 함유 한 $50 \%$ water:ACN(1:1, v/v)으로 하였으며, 형광검출기 파장 $\mathrm{Ex}=333 \mathrm{~nm}, \mathrm{Em}=460 \mathrm{~nm}$ 를 이용하여 분석을 수행하였다.

\section{검출 정량한계 및 회수율 시험}

본 연구에 사용된 분석법은 '식품 등 시험법 마련 표준절 차에 관한 가이드라인'에 준하여 시험법의 유효성을 검증하 였다(MFDS, 2016). 직선성 확인을 위해 데옥시니발레놀과 니발레놀은 $0,50,100,200,500,1,000,2,000 \mathrm{ng} / \mathrm{mL}$, 제랄 레논은 $0,2,5,10,20,50,100,200 \mathrm{ng} / \mathrm{mL}$ 농도가 되도록 검량선을 작성하였다. 아플라톡신 $\mathrm{B}_{1}, \mathrm{G}_{1}$ 은 $0,0.010 .1,0.2$, $0.5,1,2,5,10 \mathrm{ng} / \mathrm{mL}$ 아플라톡신 $\mathrm{B}_{2}, \mathrm{G}_{2}$ 는 $0,0.025,0.05$, $0.125,0.25,0.5,1.25,2.5 \mathrm{ng} / \mathrm{mL}$ 농도가 되도록 조제하였으 며, 오크라톡신 $\mathrm{A}$ 는 $0,0.5,1,2,5,10,20,50 \mathrm{ng} / \mathrm{mL}$ 농도가 되도록 조제하였다. 농도별 표준물질은 각각의 피크 면적을 이용하여 검량선을 작성하였으며, 검량선의 결정계수를 구하 
였다. 시험법의 정확성 및 정밀성을 확인하기 위해 독소에 오 염되지 않은 생강에 표준물질을 첨가한 후 분석하여 회수율 및 상대표준편차(relative standard deviation, RSD)를 산출하 였다. 데옥시니발레놀과 니발레놀은 $200,500,1000 \mu \mathrm{g} / \mathrm{kg}$ 수 준이 되도록 첨가하였으며, 제랄레논은 $50,100,200 \mu \mathrm{g} / \mathrm{kg}$ 수준으로 첨가하였다. 아플라톡신은 $\mathrm{B}_{1}, \mathrm{G}_{1}$ 은 $2,5,10 \mu \mathrm{g} / \mathrm{kg}$ 이 되도록 첨가하였으며 $\mathrm{B}_{2}, \mathrm{G}_{2}$ 는 $0.5,1.25,2.5 \mu \mathrm{g} / \mathrm{kg}$ 이 되 도록 첨가하였다. 오크라톡신 $\mathrm{A}$ 는 $2,5,10 \mu \mathrm{g} / \mathrm{kg}$ 이 되도록 첨가하여 회수율을 조사하였다. 회수율 실험은 3 반복을 수 행하였으며, 회수율 평균과 $\mathrm{RSD}$ 를 계산하여 시험법의 정확 도 및 정밀도를 평가하였다. 검출한계는 크로마토그램 상에 서 신호 대 잡음비(signal/noise ratio)를 3으로 정량한계는 검 출한계의 3 배 이상으로 하였다.

\section{통계분석}

저장 실험 결과는 SPSS 통계처리 프로그램(IBM SPSS Statistics 20, SPSS Inc., NY, USA)를 사용하여 결과값에 대해 ANOVA 검정을 실시한 후 유의적인 경우( $\mathrm{p}<0.05)$ Duncan's multiple range test로 통계학적 유의성을 조사하였다. 모든 실험은 3 반복을 수행하였다.

\section{결과 및 고찰}

\section{곰팡이독소의 검량선, 검출한계 및 정량한계, 회수율 및 재현성}

검량선의 결정계수 $\left(\mathrm{R}^{2}\right)$ 는 0.9992 이상으로 적합한 수준이
었으며(Data not shown), 회수율과 검출 및 정량한계는 Table 1에 나타내었다. 본 연구 방법은 회수율 $70.9 \%$ 이상과 정밀성 $15.4 \%$ 이하의 $\mathrm{RSD}$ 를 나타내어, 식약처의 '식품 등 시험법 마련 표준절차에 관한 가이드라인'의 회수율 및 정밀 성 유효범위를 만족하였다. 데옥시니발레놀과 니발레놀의 검 출 및 정량한계는 Bryla 등(2018)이 제시한 검출한계 각각 $4.8,10.1 \mu \mathrm{g} / \mathrm{kg}$ 와 정량한계 각각 $16.8,33.1 \mu \mathrm{g} / \mathrm{kg}$ 보다 높았 으며, 제랄레논의 검출 및 정량한계는 Ibanez-Vea 등(2011) 이 보고한 $0.3,6.0 \mu \mathrm{g} / \mathrm{kg}$ 보다 높았다. 아플라톡신의 검출 및 정량한계는 Wen 등(2013)이 보고한 검출 $(0.03-0.2 \mu \mathrm{g} / \mathrm{kg})$ 및 정량한계 $(0.1-0.6 \mu \mathrm{g} / \mathrm{kg})$ 보다 낮았으며, 동일한 문헌에서 보고 한 오크라톡신 $\mathrm{A}$ 의 검출 $(0.1 \mu \mathrm{g} / \mathrm{kg})$ 및 정량한계 $(0.9 \mu \mathrm{g} / \mathrm{kg})$ 보다 높은 수준이었다. 각각의 곰팡이독소의 크로마토그램을 Fig. 1에 나타내었다.

\section{국내산 생강의 곰팡이독소 오염현황}

Fusarium 속은 토양에서 흔하게 서식하는 대표적인 토양 전염성 병원균으로 그 중 일부는 독소를 생성하는 곰팡이다. F. graminearum은 데옥시니발레놀을, F. asiaticum은 니발레놀 을 주로 생성하며 제랄레논은 F. graminearum과 F. culmorum 종에 의해 주로 생성된다(Lee 등, 2012). 아플라톡신은 Aspergillus flavus와 A. parasiticus에 의해 주로 생성되며, 오크라톡신 A 는 A. ochraceus 와 Penicillium verrucosum에 의해 주로 생성 된다(Marin 등, 2013; Van der Merwe 등, 1965).

국내산 생강과 생강가루의 곰팡이독소 오염을 조사한 결 과 오염율은 각각 $37.03 \%$ 와 $41.17 \%$ 로 유사한 수준이었다

Table 1. Recovery, precision, limits of detection (LOD), and limits of quantification (LOQ) of mycotoxins analyzed in this study

\begin{tabular}{|c|c|c|c|c|c|}
\hline \multirow{2}{*}{ Mycotoxin $^{1)}$} & \multicolumn{3}{|c|}{ Recovery $^{2)}(\%) \pm \operatorname{RSD}^{3)}(\%)$} & \multirow{2}{*}{$\begin{array}{c}\text { LOD } \\
(\mu \mathrm{g} / \mathrm{kg})\end{array}$} & \multirow{2}{*}{$\begin{array}{c}\text { LOQ } \\
(\mu \mathrm{g} / \mathrm{kg})\end{array}$} \\
\hline & Low level & Medium level & High level & & \\
\hline DON & $93.86 \pm 5.14$ & $93.97 \pm 1.19$ & $90.02 \pm 1.04$ & 17.00 & 50.00 \\
\hline NIV & $82.46 \pm 2.97$ & $84.66 \pm 0.91$ & $79.61 \pm 0.96$ & 17.00 & 50.00 \\
\hline ZEA & $77.04 \pm 13.63$ & $83.15 \pm 2.45$ & $86.66 \pm 3.71$ & 3.00 & 9.00 \\
\hline OTA & $83.91 \pm 10.53$ & $88.71 \pm 3.58$ & $85.64 \pm 2.08$ & 0.35 & 1.20 \\
\hline $\mathrm{AFB}_{1}$ & $76.70 \pm 3.26$ & $78.96 \pm 4.49$ & $77.31 \pm 1.74$ & 0.03 & 0.10 \\
\hline $\mathrm{AFB}_{2}$ & $79.07 \pm 10.17$ & $84.07 \pm 6.04$ & $89.44 \pm 0.08$ & 0.01 & 0.03 \\
\hline $\mathrm{AFG}_{1}$ & $76.54 \pm 3.66$ & $74.14 \pm 15.42$ & $81.56 \pm 5.07$ & 0.03 & 0.10 \\
\hline $\mathrm{AFG}_{2}$ & $76.85 \pm 3.52$ & $77.94 \pm 11.70$ & $85.88 \pm 4.04$ & 0.01 & 0.03 \\
\hline
\end{tabular}

${ }^{1)} \mathrm{DON}$, deoxynivalenol; NIV, nivalenol; ZEA, zearalenone; OTA, ochratoxin $\mathrm{A} ; \mathrm{AFB}_{1}$, aflatoxin $\mathrm{B}_{1} ; \mathrm{AFB}_{2}$, aflatoxin $\mathrm{B}_{2} ; \mathrm{AFG}_{1}$, aflatoxin $\mathrm{G}_{1}$; $\mathrm{AFG}_{2}$, aflatoxin $\mathrm{G}_{2}$.

${ }^{2)} \mathrm{DON}$, NIV: $200 \mu \mathrm{g} / \mathrm{kg}$ (low level), $500 \mu \mathrm{g} / \mathrm{kg}$ (medium level), 1,000 $\mu \mathrm{g} / \mathrm{kg}$ (high level); ZEA: $50 \mu \mathrm{g} / \mathrm{kg}$ (low level), $100 \mu \mathrm{g} / \mathrm{kg}$ (medium level), $200 \mu \mathrm{g} / \mathrm{kg}$ (high level); OTA, AFB $1, \mathrm{AFG}_{1}: 2 \mu \mathrm{g} / \mathrm{kg}$ (low level), $5 \mu \mathrm{g} / \mathrm{kg}$ (medium level), $10 \mu \mathrm{g} / \mathrm{kg}$ (high level); $\mathrm{AFB}_{2}, \mathrm{AFG}_{2}: 0.5 \mu \mathrm{g} / \mathrm{kg}$ (low level), $1.25 \mu \mathrm{g} / \mathrm{kg}$ (medium level), $2.5 \mu \mathrm{g} / \mathrm{kg}$ (high level).

${ }^{3)} \mathrm{RSD}$, relative standard deviation. 
(A)
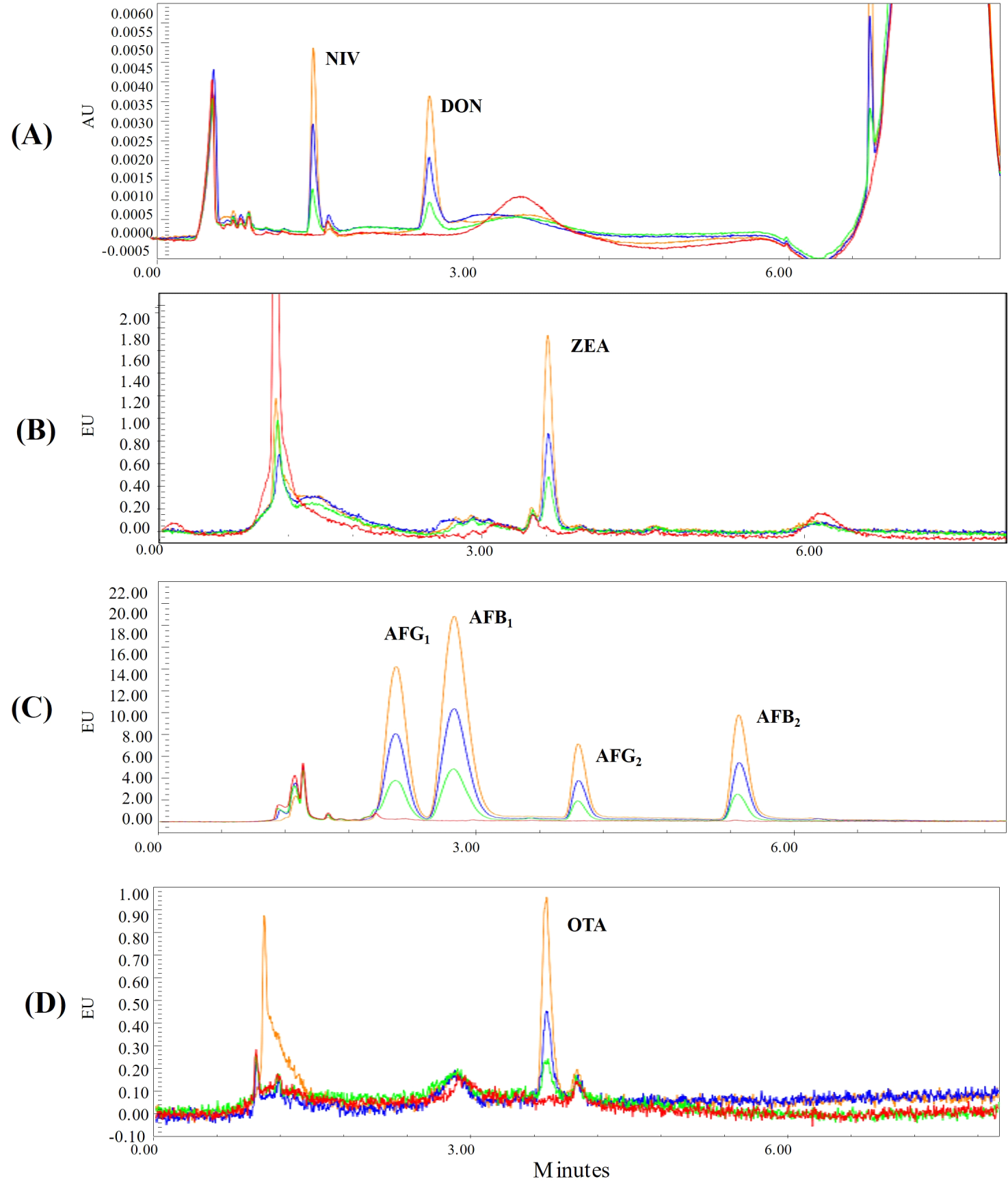

Fig. 1. UPLC chromatograms of blank ginger sample spiked with mycotoxins.

(A) NIV (nivalenol), DON (deoxynivalenol): 200 (green line), 500 (blue line), and 1,000 $\mu \mathrm{g} / \mathrm{kg}$ (red line). (B) ZEA (zearalenone): 50 (green line), 100 (blue line), and $200 \mu \mathrm{g} / \mathrm{kg}$ (red line). (C) $\mathrm{AFG}_{1}$ (aflatoxin $\mathrm{G}_{1}$ ), $\mathrm{AFB}_{1}$ (aflatoxin $\mathrm{B}_{1}$ ): 2 (green line), 5 (blue line), and $10 \mu \mathrm{g} / \mathrm{kg}$ (red line); $\mathrm{AFG}_{2}$ (aflatoxin $\mathrm{G}_{2}$ ), $\mathrm{AFB}_{2}$ (aflatoxin $\mathrm{B}_{2}$ ): 0.5 (green line), 1.25 (blue line), and $2.5 \mu \mathrm{g} / \mathrm{kg}$ (red line). (D) OTA (ochratoxin A): 2 (green line), 5 (blue line), and 10 (red line) $\mu \mathrm{g} / \mathrm{kg}$.

(Table 2). 생 생강은 니발레놀 오염율(37.03\%) 및 오염수준 (24.74-263.40 $\mu \mathrm{g} / \mathrm{kg})$ 이 가장 높았으며, 제랄레논, 오크라톡 신 $\mathrm{A}$, 데옥시니발레놀, 아플라톡신이 모두 1 건 이상 검출되었 으나 오염수준은 낮았다. 생강에서 아플라톡신 $\mathrm{B}_{1}$ 의 오염수준
은 $0.07 \mu \mathrm{g} / \mathrm{kg}$ 으로 우리나라의 최대허용기준치 $(10 \mu \mathrm{g} / \mathrm{kg})$ 의 $0.7 \%$ 수준으로 매우 낮았다. 기준 미설정 독소인 오크라톡신 $\mathrm{A}$, 데옥시니발레놀, 니발레놀, 제랄레논의 경우 곡류의 기준 을 적용했을 때 기준치(오크라톡신: $5 \mu \mathrm{g} / \mathrm{kg}$, 데옥시니발레 
Table 2. Incidence and levels of mycotoxin in Korean ginger and ginger powder

\begin{tabular}{|c|c|c|c|c|c|c|}
\hline & \multirow{2}{*}{$\begin{array}{c}\text { Incidence }(\%) \\
\text { (Detection/sample) }\end{array}$} & \multicolumn{5}{|c|}{$\begin{array}{l}\text { Mycotoxin levels }(\mu \mathrm{g} / \mathrm{kg}) \\
\text { (Number of positive sample) }^{1)}\end{array}$} \\
\hline & & $\mathrm{DON}^{2)}$ & NIV & ZEA & OTA & Total AFs \\
\hline Ginger & $37.03 \%(10 / 27)$ & $61.75(1)$ & $24.74-263.40(10)$ & $3.00-15.73(5)$ & $0.35-0.67$ (3) & $0.07\left(\mathrm{AFB}_{1}\right)$ \\
\hline Ginger powder & $41.17 \%(7 / 17)$ & $17.62-401.58(6)$ & $73.24-439.65(5)$ & $5.80-97.84$ (4) & $\mathrm{ND}^{3)}$ & ND \\
\hline
\end{tabular}

${ }^{1)}$ Mycotoxin level >LOD (DON, NIV: $17.00 \mu \mathrm{g} / \mathrm{kg}$; ZEA: $3.00 \mu \mathrm{g} / \mathrm{kg}$; OTA: $0.35 \mu \mathrm{g} / \mathrm{kg} ; \mathrm{AFB}_{1}, \mathrm{AFG}_{1}: 0.03 \mu \mathrm{g} / \mathrm{kg} ; \mathrm{AFB}_{2}, \mathrm{AFG}_{2}: 0.01 \mu \mathrm{g} / \mathrm{kg}$ ). ${ }^{2}$ DON, deoxynivalenol; NIV, nivalenol; ZEA, zearalenone; OTA, ochratoxin A; AFs, Aflatoxins $\left(\mathrm{B}_{1}, \mathrm{~B}_{2}, \mathrm{G}_{1}, \mathrm{G}_{2}\right)$; $\mathrm{AFB}_{1}$, aflatoxin $\mathrm{B}_{1}$. ${ }^{3} \mathrm{ND}$, not detected.

놀: $1,000 \mu \mathrm{g} / \mathrm{kg}$, 제랄레논: $100 \mu \mathrm{g} / \mathrm{kg}$; 니발레놀은 기준이 없어 데옥시니발레놀과 동일한 $1,000 \mu \mathrm{g} / \mathrm{kg}$ 을 적용)의 $6.18-$ $26.34 \%$ 로 안전한 것으로 생각된다. 생강가루는 데옥시니발 레놀(35.29\%) > 니발레놀 $(29.41 \%)>$ 제랄레논(23.53\%) 순 으로 오염율이 높았으며, 아플라톡신과 오크라톡신 A는 불 검출되었다. 생강가루의 데옥시니발레놀, 니발레놀, 제랄레 논의 오염수준은 생 생강에 비해 높았으나 데옥시니발레놀을 제외하고 통계적으로 유의차는 없었다(Data not shown). 생 강가루 조제시 품질이 좋지 않은 생강을 이용할 경우 곰팡이 독소 오염수준이 높을 수 있다(Yang 등, 2019). 또한, 입자가 작고 접촉표면이 클수록 곰팡이독소 생성에 유리할 수 있기 때문에 생강보다 생강가루에서 곰팡이독소 오염수준이 높은 것으로 판단된다.

국내산 농산물의 곰팡이독소 오염사례를 살펴보면 곰팡이 독소 오염율과 오염수준은 품목별로 차이가 있었다. Kim 등 (2013)은 국내산 곡류에서 곰팡이독소 오염을 조사한 결과, 백미와 보리에서 제랄레논의 오염율은 각각 $36.2 \%$ 와 $34.9 \%$ 이었으며, 최대오염량은 각각 $6.66 \mu \mathrm{g} / \mathrm{kg}, 8.95 \mu \mathrm{g} / \mathrm{kg}$ 이었다 고 보고하였다. 또한, 백미와 보리에서 데옥시니발레놀의 오염 율은 각각 $6.4 \%, 55.8 \%$ 이었으며 최대오염량은 $93.10 \mu \mathrm{g} / \mathrm{kg}$, $334.0 \mu \mathrm{g} / \mathrm{kg}$ 으로 보리의 오염율과 오염수준이 상대적으로 높 았다고 보고하였다. Jang 등(2008)은 두류 중 제랄레논의 오 염율 및 오염수준은 각각 $10.2 \%, 8.01-38.98 \mu \mathrm{g} / \mathrm{kg}$ 이었다고 보고하였다. Park 등(2013)은 유통식품 151건을 조사한 결과 아플라톡신과 오크라톡신 A가 검출되었으며, 아플라톡신이 검출된 품목은 수수 $(0.32 \mu \mathrm{g} / \mathrm{kg})$, 잣 $(1.80 \mu \mathrm{g} / \mathrm{kg})$, 고추장 $(0.40-0.55 \mu \mathrm{g} / \mathrm{kg})$, 땅콩버터( $0.33-0.99 \mu \mathrm{g} / \mathrm{kg})$, 고춧가루 $(0.25-$ $0.91 \mu \mathrm{g} / \mathrm{kg}$ ) 등이었으며 오크라톡신 A가 검출된 품목은 건포 도 $(0.97 \mu \mathrm{g} / \mathrm{kg})$ 이었다고 보고하였다. 2018년 식약처의 식품 의 곰팡이독소 기준 · 규격 재평가 보고서에 따르면 국내 생 강 및 생강가루에서 곰팡이독소는 검출되지 않았다(MFDS, 2018b). 그러나 Choi 등(2021)은 한약제로 사용되는 국내산 생강(건강) 16점에 대해 아플라톡신, 오크라톡신 A, 푸모니 신, 제랄레논의 오염을 조사한 결과, 4점(25.0\%)에서 제랄레
논이 3.89-15.96 $\mu \mathrm{g} / \mathrm{kg}$ 수준으로 검출되었으며 다른 독소는 검출되지 않았다고 보고하였다. 이는 본 연구 결과에서 아플 라톡신과 오크라톡신 $\mathrm{A}$ 는 거의 검출되지 않고 제랄레논은 검출된 결과와 유사하며 제랄레논의 오염율과 오염수준 또한 유사하였다.

국외 생강의 곰팡이독소 연구사례를 살펴보면 국가별로 차이를 보였다. Wen 등(2013)은 중국의 생강과 생강가루에 대해 아플라톡신과 오크라톡신 $\mathrm{A}$ 의 오염을 조사한 결과, 생 강에서는 독소가 검출되지 않았으나, 생강가루에서는 아플라 톡신 $\mathrm{B}_{1}$ 과 $\mathrm{G}_{2}$ 가 정량한계 이하 $\left(\mathrm{B}_{1}: 0.3, \mathrm{G}_{2}: 0.2 \mu \mathrm{g} / \mathrm{kg}\right.$ )로 검 출되었다고 보고하였다. 또한, 곰팡이가 핀 생강 시료 3점에 서 오크라톡신 A가 0.32-5.17 $\mu \mathrm{g} / \mathrm{kg}$ 수준으로 검출되었으며, 생강 티백 6점 중 5점에서 아플라톡신 $\mathrm{B}_{1}$ 이 $0.13-1.38 \mu \mathrm{g} / \mathrm{kg}$ 수준으로 검출되었다고 보고하였다(Wen 등, 2014). 터키에 서는 생강의 아플라톡신 $\mathrm{B}_{1}$ 의 오염을 조사한 결과, $75 \%$ 의 오 염율을 나타내었으며, 오염수준은 3.8-23.1 $\mu \mathrm{g} / \mathrm{kg}$ 으로 높았다 고 보고하였다(Tosun과 Arslan, 2013). Koul과 Sumbali(2008) 는 인도산 생강 27 점에 대해 제랄레논과 데옥시니발레놀을 조사한 결과 2점(7.4\%)에서 제랄레논이 13.44-14.51 $\mu \mathrm{g} / \mathrm{kg}$ 수 준으로 검출되었으며, 데옥시니발레놀은 4점(14.8\%)에서 4.85$10.35 \mu \mathrm{g} / \mathrm{kg}$ 수준으로 검출되었다고 보고하였다. 국외 생강 의 곰팡이독소 연구 결과를 비교했을 때 국내 생강의 아플라 톡신과 오크라톡신 $\mathrm{A}$ 의 오염수준은 외국에 비해 낮았으나, 데옥시니발레놀, 니발레놀, 제랄레논의 오염수준은 상대적으 로 높은 편이었다. 국내 생강의 Fusarium 독소 오염수준이 외국보다 높은 이유에 대한 추가적인 연구가 필요할 것으로 판단된다.

시료의 곰팡이독소 중복 오염을 조사한 결과, $25.93 \%$ 의 생 강 시료가 두 종 이상의 곰팡이독소에 오염된 것으로 나타났 다(Table 3). 특히 니발레놀과 제랄레논의 중복 오염은 중복 오염된 생강시료의 $71.43 \%(5 / 7)$ 로 대부분을 차지하였다. 생 강가루의 곰팡이독소 중복 오염율은 $29.41 \%$ 였으며, 중복 오 염된 독소의 조합으로는 데옥시니발레놀과 니발레놀 또는 데 옥시니발레놀, 니발레놀, 제랄레논으로 모두 Fusarium 속 곰 
Table 3. Co-occurrence of mycotoxins in Korean ginger and ginger powder

\begin{tabular}{cccc}
\hline \multirow{2}{*}{ Number of mycotoxins } & Type of co-occurring mycotoxins ${ }^{1)}$ & \multicolumn{2}{c}{ Number of positive samples ${ }^{2)}$} \\
\cline { 3 - 4 } & & GON, NIV & Ginger powder $(\mathrm{n}=27)$ \\
\hline & NIV, ZEA & 1 & 2 \\
& ZEA, OTA & 5 & 0 \\
\hline 3 & DON, NIV, ZEA & 1 & 3 \\
\hline Total $(\%)$ & & $7(25.93)$ & $5(29.41)$ \\
\hline
\end{tabular}

${ }^{1)} \mathrm{DON}$, deoxynivalenol; NIV, nivalenol; ZEA, zearalenone; OTA, ochratoxin A.

${ }^{2)}$ Mycotoxin level $>$ limit of detection.

팡이가 생성하는 독소였다. Fusarium 독소의 경우 한 균주가 다양한 Fusarium 독소를 생성할 수 있기 때문에 중복 오염이 쉽게 발생되며(Smith 등, 2016), 독소가 중복 오염될 경우 위 해도가 단일독소보다 높아질 수 있다(Speijers과 Speijers, 2004). 따라서 향후 위해성 평가를 위한 곰팡이독소 모니터 링 시 중복 오염 여부를 함께 검토하는 것이 필요할 것으로 판단된다.

국내의 경우 외국과 달리 생강에서 아플라톡신과 오크라 톡신 A의 오염이 거의 발생하지 않은 반면 데옥시니발레놀, 니발레놀, 제랄레논의 오염이 주로 발생하였다. 생강은 4월 에 파종하여 10 월 중순에서 11 월 초에 수확하기 때문에 기상 조건이 Aspergillus와 Penicillium의 생장에 적합하지 않은 것 으로 판단된다. 그러나 지구 온난화로 인한 연평균 기온 상승 및 잦은 강우 등으로 향후 아플라톡신과 오크라톡신 $\mathrm{A}$ 의 오 염도 발생할 수 있어 이를 대비한 선제적인 오염 모니터링이 필요할 것으로 판단된다. 생강의 국내 곰팡이독소 기준을 살 펴보면 아플라톡신 $\left(\mathrm{B}_{1}, \mathrm{~B}_{2}, \mathrm{G}_{1}\right.$ 및 $\mathrm{G}_{2}$ 의 합)에 대해 15.0 $\mu \mathrm{g} / \mathrm{kg}$ 기준이 설정되어 있으며( $\mathrm{B}_{1}$ 은 $10.0 \mu \mathrm{g} / \mathrm{kg}$ 이하) 다른 독소에 대해서 기준이 설정되어 있지 않다(MFDS, 2018a). 유럽의 경우 생강은 아플라톡신 $\mathrm{B}_{1}$ 에 대해 $5 \mu \mathrm{g} / \mathrm{kg}$, 아플라 톡신 총합에 대해 $10 \mu \mathrm{g} / \mathrm{kg}$, 그리고 오크라톡신 $\mathrm{A}$ 에 대해 15 $\mu \mathrm{g} / \mathrm{kg}$ 의 기준이 설정되어 있다(EC, 2006). 생강은 본 연구에 서와 같이 우리나라의 기후 및 생강의 재배 특성상 Fusarium 속 균에 의한 곰팡이독소가 주로 발생할 수 있기 때문에 Fusarium 독소를 중심으로 오염 모니터링을 통한 위해 평가 와 관리기준 설정 검토 및 저감화 연구가 진행되어야 할 것으 로 생각된다.

\section{저장조건에 따른 곰팡이독소의 오염도}

Table 4는 생산지역이 서로 다른 생강 시료(A, B)를 세 가 지 저장조건에서 6 개월 동안 저장하면서 곰팡이독소 오염을 조사한 결과이다. 저장조건에 따른 데옥시니발레놀과 제랄레
논의 오염수준은 $\mathrm{A}$ 와 $\mathrm{B}$ 시료 모두 $14^{\circ} \mathrm{C} / 68 \%$ 조건에서 가장 높았다. $14^{\circ} \mathrm{C} / 68 \%$ 조건에서 저장한 $\mathrm{B}$ 시료의 데옥시니발레놀 오염농도는 저장 2 개월 후 최대 $955.23 \mu \mathrm{g} / \mathrm{kg}$ 으로 가장 높았 으며, 제랄레논의 오염농도는 저장 4 개월 후 $342.74 \mu \mathrm{g} / \mathrm{kg}$ 으 로 가장 높게 나타났다. 니발레놀은 $5{ }^{\circ} \mathrm{C} / 73 \%$ 조건에서 4 개월 동안 저장한 A 시료에서 니발레놀 오염수준은 $701.58 \mu \mathrm{g} / \mathrm{kg}$ 으로 가장 높았으며, $13^{\circ} \mathrm{C} / 96 \%$ 조건에서 오염수준이 가장 낮 았다. 한편, 아플라톡신과 오크라톡신 $\mathrm{A}$ 는 저장기간(6개월) 동안 독소가 불검출되었다(Data not shown).

재배기 및 수확기에 감염된 독성곰팡이는 저장 중에도 곰 팡이독소를 생성할 수 있다(Marin 등, 2013; Milicevie 등, 2010). 생강은 수확 후 세척 과정 없이 토굴 또는 저온창고에 저장된다. 즉, 흙이 묻어 있는 상태로 저장되기 때문에 미생 물이 침입하기 쉬워 환경이 맞지 않으면 저장 중 부패가 쉽게 일어날 수 있다. 생강 저장시 $10^{\circ} \mathrm{C}$ 이하의 온도에서는 저온장 해가 발생하여 부패가 촉진되고, $18^{\circ} \mathrm{C}$ 이상에서는 발아 및 위 조현상으로 인해 상품성을 잃을 수 있으며, $90 \%$ 이하의 상대 습도에서는 곰팡이에 의한 부패율이 늘어난다고 알려져 있다 (RDA, 2005). Jeong 등(1998)은 $7,12,20^{\circ} \mathrm{C}$ 의 온도와 $75 \%$, $85 \%, 95 \%$ 의 상대습도에서 각각 저장하면서 생강의 품질을 비교한 결과, $7^{\circ} \mathrm{C}$ 와 $20^{\circ} \mathrm{C}$ 에서 습도 조건별로 저장한 생강에 서는 각각 저온장해와 발아 현상으로 인해 품질저하가 빠르 게 진행되었고, $12^{\circ} \mathrm{C} / 75 \%$ 인 경우에는 $7^{\circ} \mathrm{C}$ 의 저장 생강과 유 사할 정도로 품질변화가 크게 나타난 반면, $12^{\circ} \mathrm{C} / 95 \%$ 에 저장 한 생강에서는 중량감소율, 부패율, 발아율 등의 모든 품질적 측면에서 가장 우수한 결과를 나타내었다고 보고하였다. 이 는 본 연구에서 $13^{\circ} \mathrm{C} / 96 \%$ 에서 저장한 생강이 다른 조건에 비 해 데옥시니발레놀과 니발레놀의 오염이 상당히 낮은 결과와 매우 유사하였다. 이 조건은 생강의 부패율과 상품성을 고려 한 권장 저장조건이므로 생강을 저장할 때는 $13^{\circ} \mathrm{C} / 96 \%$ 전후 의 온·습도에서 보관하는 것이 곰팡이독소를 예방하고 생 강의 부패율을 감소시키는 데 도움이 될 것으로 판단된다. 현 
Table 4. Level of deoxynivalenol, nivalenol, and zearalenone in Korean ginger stored at different storage conditions

\begin{tabular}{|c|c|c|c|c|c|}
\hline \multirow{2}{*}{ Sample } & \multirow{2}{*}{ Mycotoxin $^{1)}$} & \multirow{2}{*}{ Storage periods (mon) } & \multicolumn{3}{|c|}{ Temperature/relative humidity } \\
\hline & & & $5^{\circ} \mathrm{C} / 73 \%$ & $13^{\circ} \mathrm{C} / 96 \%$ & $14^{\circ} \mathrm{C} / 68 \%$ \\
\hline \multirow{15}{*}{ A } & \multirow{5}{*}{ DON } & 0 & $<\mathrm{LOD}^{2)}$ & $<\mathrm{LOD}$ & $<\mathrm{LOD}$ \\
\hline & & 2 & $19.22 \pm 5.0^{\mathrm{c} 3)}$ & $94.83 \pm 6.51^{\mathrm{b}}$ & $186.90 \pm 30.91^{\mathrm{a}}$ \\
\hline & & 4 & $67.89 \pm 8.93^{\mathrm{a}}$ & $19.69 \pm 2.87^{\mathrm{b}}$ & $<\mathrm{LOD}$ \\
\hline & & 6 & $32.78 \pm 2.70^{\mathrm{a}}$ & $\mathrm{ND}^{4)}$ & $65.46 \pm 18.81^{\mathrm{a}}$ \\
\hline & & Mean $^{5)}$ & $33.46 \pm 22.43^{\mathrm{a}}$ & $32.12 \pm 38.67^{\mathrm{a}}$ & $65.46 \pm 75.96^{\mathrm{a}}$ \\
\hline & \multirow{5}{*}{ NIV } & 0 & $125.42 \pm 4.44$ & $125.42 \pm 4.44$ & $125.42 \pm 4.44$ \\
\hline & & 2 & $545.22 \pm 36.07^{\mathrm{a}}$ & $39.70 \pm 0.43^{\mathrm{c}}$ & $315.20 \pm 16.69^{\mathrm{b}}$ \\
\hline & & 4 & $701.58 \pm 79.60^{\mathrm{a}}$ & $234.56 \pm 23.53^{\mathrm{b}}$ & $132.21 \pm 9.51^{\mathrm{c}}$ \\
\hline & & 6 & $471.89 \pm 50.66^{\mathrm{a}}$ & $25.88 \pm 6.03^{b}$ & $514.82 \pm 153.31^{\mathrm{a}}$ \\
\hline & & Mean & $461.03 \pm 224.33^{\mathrm{a}}$ & $106.39 \pm 87.58^{\mathrm{c}}$ & $271.91 \pm 179.23^{b}$ \\
\hline & \multirow{5}{*}{ ZEA } & 0 & $9.74 \pm 2.74$ & $9.74 \pm 2.74$ & $9.74 \pm 2.74$ \\
\hline & & 2 & ND & ND & $178.79 \pm 39.31^{\mathrm{a}}$ \\
\hline & & 4 & ND & $49.02 \pm 1.48^{\mathrm{a}}$ & ND \\
\hline & & 6 & ND & $5.82 \pm 2.57^{\mathrm{a}}$ & $\mathrm{ND}$ \\
\hline & & Mean ${ }^{5}$ & $<$ LOD & $16.15 \pm 20.23^{\mathrm{ab}}$ & $47.13 \pm 81.26^{\mathrm{a}}$ \\
\hline \multirow{15}{*}{$\mathrm{B}$} & \multirow{5}{*}{ DON } & 0 & $<\mathrm{LOD}$ & $<\mathrm{LOD}$ & $<\mathrm{LOD}$ \\
\hline & & 2 & $255.41 \pm 21.15^{\mathrm{b}}$ & $21.83 \pm 0.22^{\mathrm{c}}$ & $798.92 \pm 21.82^{\mathrm{a}}$ \\
\hline & & 4 & $140.97 \pm 26.98^{\mathrm{b}}$ & ND & $955.23 \pm 38.38^{\mathrm{a}}$ \\
\hline & & 6 & $<$ LOD & ND & $656.20 \pm 125.75^{\mathrm{a}}$ \\
\hline & & Mean & $104.05 \pm 108.15^{\mathrm{b}}$ & $<\mathrm{LOD}$ & $616.55 \pm 387.62^{\mathrm{a}}$ \\
\hline & \multirow{5}{*}{ NIV } & 0 & $<\mathrm{LOD}$ & $<\mathrm{LOD}$ & $<\mathrm{LOD}$ \\
\hline & & 2 & $229.71 \pm 24.49^{\mathrm{a}}$ & $<\mathrm{LOD}$ & $113.84 \pm 5.74^{\mathrm{b}}$ \\
\hline & & 4 & $81.39 \pm 4.90^{\mathrm{b}}$ & $\mathrm{ND}$ & $137.37 \pm 27.17^{\mathrm{a}}$ \\
\hline & & 6 & $27.73 \pm 1.17^{\mathrm{a}}$ & $\mathrm{ND}$ & $17.62 \pm 6.52^{\mathrm{b}}$ \\
\hline & & Mean & $88.54 \pm 89.62^{\mathrm{a}}$ & $<\mathrm{LOD}$ & $71.05 \pm 58.92^{\mathrm{a}}$ \\
\hline & \multirow{5}{*}{ ZEA } & 0 & ND & $\mathrm{ND}$ & ND \\
\hline & & 2 & ND & $\mathrm{ND}$ & $39.07 \pm 34.40^{\mathrm{a}}$ \\
\hline & & 4 & ND & ND & $342.74 \pm 37.90^{\mathrm{a}}$ \\
\hline & & 6 & ND & N.D & $139.64 \pm 15.63^{\mathrm{a}}$ \\
\hline & & Mean & ND & $\mathrm{ND}$ & $130.36 \pm 140.55^{\mathrm{a}}$ \\
\hline
\end{tabular}

${ }^{1)} \mathrm{DON}$, deoxynivalenol; NIV, nivalenol; ZEA, zearalenone.

${ }^{2} \mathrm{LOD}$, limit of detection (deoxynivalenol, nivalenol: $17 \mu \mathrm{g} / \mathrm{kg}$; zearalenone: $3 \mu \mathrm{g} / \mathrm{kg}$ ).

${ }^{3)}$ Values are mean $\pm \mathrm{SD} \mu \mathrm{g} / \mathrm{kg}$, Means with the different letter within rows were significantly different $(\mathrm{p}<0.05)$.

${ }^{4)} \mathrm{ND}$, not detected.

${ }^{5)}$ Average of all periods. 
장에서 사용되는 저온창고 조건은 온도는 적합하나 습도가 $70 \%$ 이하 수준으로 낮기 때문에 습도를 $96 \%$ 수준으로 높여 서 저장하는 것이 필요할 것으로 판단된다.

Versonder 등(1982)은 옥수수에서 F. graminearum과 $F$. roseum의 데옥시니발레놀 생성을 위한 최적온도는 각각 $29-30^{\circ} \mathrm{C}, 25-26^{\circ} \mathrm{C}$ 였으며, 최저온도는 약 $11^{\circ} \mathrm{C}$ 일 것으로 예측 하였다. Megan과 Lacey(1984)는 F. culmorum, F. poae, F. avenaceum 종의 최적 생장온도는 $20-25^{\circ} \mathrm{C}$ 였고, $5-10^{\circ} \mathrm{C}$ 와 $35^{\circ} \mathrm{C}$ 에서는 생장이 감소했다고 하였으며, 최적온도에서 최적수분 활성도는 0.98-0.995, 최소수분활성도는 0.90-0.91이었다고 보고하였다. Wawrzyniak 등(2013)은 보리에서 곰팡이의 생 장은 저장온도보다 수분활성도가 더 큰 영향을 준다고 보고하 였다. 그러나 Hope 등(2005)은 F. culmorum과 F. graminearum 를 인공 접종한 밀에서는 온도와 수분활성도가 높을수록 곰 팡이의 생장이 증가했다고 보고하였다. Zhang 등(2019)은 밀 을 $15^{\circ} \mathrm{C} / 50 \%, 20{ }^{\circ} \mathrm{C} / 65 \%, 25^{\circ} \mathrm{C} / 75 \%, 30^{\circ} \mathrm{C} / 80 \%$ 조건에서 보 관하면서 Fusarium 독소의 오염을 조사한 결과, 저장 6개월 후 $25^{\circ} \mathrm{C} / 75 \%$ 조건에서 데옥시니발레놀의 오염 수준은 1,103 $\mu \mathrm{g} / \mathrm{kg}$ 으로 가장 높았다고 보고하였다. 또한, 저장온도와 상 대습도가 낮았을 때 Fusarium 독소 또한 오염수준이 낮았다 고 보고하였다. 이러한 결과는 본 연구에서 상대습도가 $70 \%$ 이하였던 두 조건보다 $96 \%$ 였던 조건에서 생강의 곰팡이독소 오염이 낮았던 결과와 달랐다. 생강의 수분함유량은 $83 \%$ 로 매우 높으며 곡류의 수분함유량은 $14-23 \%$ 로 낮은 편에 속한 다(RDA, 2005; RDA, 2018a; RDA, 2018b). 따라서 곰팡이 독소 저감 저장조건은 작물의 수분함유량에 따라 달라질 수 있을 것으로 판단된다. 고온성 작물인 생강은 저온에서 장해 를 입어 곰팡이 침입이 증가하여 독소가 많이 발생하며 비교 적 높은 저장온도인 $13^{\circ} \mathrm{C}$ 와 수분 손실이 적은 $96 \%$ 상대습도 에서 품질이 유지되며 곰팡이 발생이 적어 독소도 적게 생성 되는 것으로 판단된다.

본 연구 결과를 종합하면 국내 생강의 곰팡이독소 오염실 태 모니터링 결과, 외국과 달리 아플라톡신과 오크라톡신 A 의 오염은 거의 없었으나 Fusarium 속 곰팡이에 의한 독소인 데옥시니발레놀, 니발레놀, 제랄레논의 오염이 주로 발생하 였고 독소의 중복 오염이 관찰되었다. 하지만 생강 및 생강가 루의 곰팡이독소 오염수준은 곡류의 곰팡이독소 최대허용량 과 비교했을 때 안전한 수준이었다. 또한, 생강의 곰팡이독소 저감화 저장조건을 조사한 결과, $13^{\circ} \mathrm{C} / 96 \%$ 조건에서 데옥시 니발레놀과 니발레놀의 오염이 가장 낮았다. 따라서 생강의 곰팡이독소 예방을 위해 이 조건으로 저장한다면 연간 저장 하면서 판매되는 생강의 곰팡이독소 오염을 보다 낮출 수 있 을 것으로 생각된다.

\section{요 약}

본 연구는 국내산 생강의 곰팡이독소 오염실태를 조사하 고 독소 저감을 위한 생강의 저장조건을 탐색하고자 수행되 었다. 총 44개의 국내산 생강(생 생강[27점], 생강가루[17점]) 에 대해 아플라톡신, 오크라톡신 $\mathrm{A}$, 데옥시니발레놀, 니발레 놀, 제랄레논의 오염도를 조사하였다. 각각의 독소는 면역친 화컬럼을 이용하여 전처리한 후 UPLC 분석을 수행하였다. 생강 시료의 $37.03 \%$ 에서 곰팡이독소가 검출되었으며, 니발 레놀의 오염율 $(37.03 \%)$ 이 가장 높았고 오염 수준은 24.74$263.40 \mu \mathrm{g} / \mathrm{kg}$ 이었다. 생강가루는 $41.17 \%$ 에서 곰팡이독소가 검출되었고, 데옥시니발레놀과 니발레놀, 제랄레논이 각각 $17.62-401.58,73.24-439.65,5.80-97.84 \mu \mathrm{g} / \mathrm{kg}$ 수준으로 검 출된 반면, 아플라톡신과 오크라톡신 $\mathrm{A}$ 는 검출되지 않았다. 또한, 생강과 생강가루의 2종 이상의 곰팡이독소 중복오염율 은 각각 $25.93 \%$ 와 $29.41 \%$ 이었다. 곰팡이독소 저감을 위한 생강의 저장조건을 탐색한 결과, $13^{\circ} \mathrm{C} / 96 \%$ 조건에서 데옥시 니발레놀과 니발레놀 오염도가 가장 낮았다. 본 연구는 국내 생강의 Fusarium 곰팡이독소 오염 및 중복 오염을 처음으로 보고하였다.

\section{감사의 글}

본 연구는 농촌진흥청 국립농업과학원 농업과학기술 연구 개발사업(과제번호: PJ014811)의 지원으로 수행되었습니다.

\section{Conflict of interests}

The authors declare no potential conflict of interest.

\section{ORCID}

Mi Jeong Lee https://orcid.org/0000-0003-1685-9584

Ja Yeong Jang https://orcid.org/0000-0002-1719-6535

\section{References}

Akhani SP, Vishwakarma SL, Goyal RK. Anti-diabetic activity of Zingiber officinale in streptozotocin-induced type I diabetic rats. J Pharm Pharmacol, 56, 101-105 (2004)

Arnold D, McGuire P, Nera E, Karpinski K, Bickis M, Zawidzka A, Fernie S, Vesonder R. The toxicity of orally administered deoxynivalenol (vomitoxin) in rats 
and mice. Food Chem Toxic, 24, 935-941 (1986)

Binder EM, Tan LM, Chin LJ, Handl J, Richard J. Worldwide occurrence of mycotoxins in commodities, feeds and feed ingredients. Anim Feed Sci Techonol, 137, 265282 (2007)

Bryla M, Ksieniewicz-Wozniak E, Waskiewicz A, Szymczyk K, Jedrzejczak R. Natural occurrence of nivalenol, deoxynivalenol, and deoxynivalenol-3-glucoside in Polish winter wheat. Toxins, 10, 81, 1-12 (2018)

Choi SJ, Ko SK, Park YA, Jung SJ, Choi EJ, Kim HU, Kim EJ, Hwang IS, Shin GY, Yu IS, Shin YS. Determination of mycotoxins in agricultural products used for food and medicine using liquid chromatography triple quadrupole mass spectrometry and their risk assessment. J Food Hyg Saf, 36, 24-33 (2021)

European Commission (EC). European commission regulation (EC) No. 1881/2006 of 19 December 2006 setting maximum levels for certain contaminants in foodstuff. Off J Eur Union, Rome, Italy, p 5-24 (2006)

European Pharmacopoeia Commission. Determination of aflatoxin $\mathrm{B}_{1}$ in herbal drugs. In: European Pharmacopoeia 9th ed, 2.8.18 (Vol. 1), Council of Europe, Strasbourg, France, p 289 (2016)

Food and Agriculture Organization. Worldwide regulations for mycotoxins in food and feed in 2003. FAO Food and Nutrition Paper, Rome, Italy, 81, 3.1-3.5 (2004)

Han Z, Ren YP, Zhu JF, Cai ZX, Chen Y, Luan LJ, Wu YJ. Multianalysis of 35 mycotoxins in traditional Chinese medicines by ultra-high-performance liquid chromatographytandem mass spectrometry coupled with accelerated solvent extraction. J Agric Food Chem, 60, 8233-8247 (2012)

Hope R, Aldred D, Magan N. Comparison of environmental profiles for growth and deoxynivalenol production by Fusarium culmorum and $F$. graminearum on wheat grain. Lett Appl Microbiol, 40, 295-300 (2005)

Ibanez-Vea M, Corcuera LA, Remiro R, Murillo-Arbizu MT, Gonzalez-Penas E, Lizarraga E. Validation of a UHPLC-FLD method for the simultaneous quantification of aflatoxins, ochratoxin A and zearalenone in barley. Food Chem, 127, 351-358 (2011)

International Agency for Research on Cancer-IARC. Evaluation of carcinogenic risks of chemical to human. In: Some Naturally-Occurring Substances: Food Items and Constituents. Heterocyclic Aromatic Amines and Mycotoxins. IARC Monographs, Lyon, France, 56, p 599 (1993)

Jang MR, Lee CH, Lee HJ, Kim JY, Son SH, Shin CS, Kim $\mathrm{SH}, \mathrm{Kim}$ DB. A survey of zearalenone in beans using high performance liquid chromatography-fluorescence detector (HPLC-FLD) and ultra performance liquid chromatography tandem mass spectrometry (LC-MS/MS). Korean J Food Sci Technol, 40, 354-359 (2008)

Japanese Pharmacopoeia Commentary Editorial Committee. The Japanese Pharmacopoeia 17th ed, (English Version), Analytical Methods for Aflatoxins in Crude Drug and Crude Drug Preparations. Japanese Pharmacopoeia Commentary Editorial Committee, Tokyo, Japan, $p$ 2513-2515 (2016)

Jeong MC, Lee SE, Nahmgung B, Chung TY, Kim DC. Changes of quality in ginger according to storage conditions. Korean J Postharvest Sci Technol, 5, 224-230 (1998)

Kim DH, Jang HS, Choi GI, Kim HJ, Kim HJ, Kim HL, Cho HJ, Lee C. Occurrence of mycotoxins in Korean grains and their simultaneous analysis. Korean $\mathrm{J}$ Food Sci Technol, 45, 111-119 (2013)

Koul A, Sumbali G. Detection of zearalenone, zearalenol and deoxynivalenol from medicinally important dried rhizomes and root tubers. Afr J Biotechnol, 7, 41364139 (2008)

Kubra IR, Rao LJM. An impression on current developments in the technology, chemistry, and biological activities of ginger (Zingiber officinale Roscoe). Crit Rev Food Sci Nutr, 52, 651-688 (2012)

Lee HJ, Ryu D. Worldwide occurrence of mycotoxins in cereals and cereal-derived food products: Public health perspectives of their co-occurrence. J Agric Food Chem, 65, 7034-7051 (2017)

Lee MJ, Wee CD, Ham H, Choi JH, Baek JS, Lim SM, Lee T, Kim JS, Jang JY. Survey on Fusarium mycotoxin contamination in oat, sorghum, adlay, and proso millet during the harvest season in Korea. J Food Hyg Saf, 35, 13-22 (2020a)

Lee SY, Woo SY, Tian F, Song J, Michlmayr H, Kim JB, Chun HS. Occurrence of deoxynivalenol, nivalenol, and their glucosides in Korean market foods and estimation of their population exposure through food consumption. 
Toxins, 12, 89, 1-12 (2020b)

Lee T, Lee S, Lee JH, Yun JC, Oh KS. Natural occurrence of mycotoxin and fungi Korean rice. Res Plant Dis, 18, 261-267 (2012)

Lippolis V, Irurhe O, Porricelli ACR, Cortese M, Schena R, Imafidon T, Oluwadun A, Pascale M. Natural cooccurrence of aflatoxins and ochratoxin $\mathrm{A}$ in ginger (Zingiber officinale) from Nigeria. Food Control, 73, 1061-1067 (2017)

Marin S, Ramos AJ, Cano-Sancho G, Sanchis V. Mycotoxins: Occurrence, toxicology, and exposure assessment. Food Chem Toxicol, 60, 218-237 (2013)

Megan N, Lacey J. The effect of temperature and $\mathrm{pH}$ on the water relations of field and storage fungi. Trans $\mathrm{Br}$ Mycol Soc, 82, 71-81 (1984)

Milicevic DR, Skrinjar M, Baltic T. Real and perceived risks for mycotoxin contamination in foods and feeds: Challenges for food safety control. Toxins, 2, 572-592 (2010)

Ministry of Agriculture, Food and Rural Affairs Republic of Korea. Agriculture, Food and Rural Affairs Statistics Yearbook 2020, Registration No. 11-1543000-000261-10, (2020)

Ministry of Food and Drug Safety. Guidelines on Standard Procedures for Preparing Test Methods, Including Food. Notification No. 2016-154, Chungju, Korea, p 17-18 (2016)

Ministry of Food and Drug Safety. Standards and Specifications for General Foods, Notification No. 201874, Chungju, Korea, p 28-30 (2018a)

Ministry of Food and Drug Safety, Report on Reevaluation of Mycotoxin Criteria in Food, Notification No. 11-1471000-000311-01, Chungju, Korea, p 217-248 (2018b)

Mirocha C, Christensen C, Nelson G. Microbial toxins. In: F-2 (Zearalenone) Estrogenic Mycotoxin from Fusarium, 7th ed, Kadis A, Ciegler A, Aji SJ (Editor), Academic Press, New York, USA, 99, 107-138 (1971)

Omotayo OP, Omotayo AO, Babalola OO, Mwanza M. Comparative study of aflatoxin contamination of winter and summer ginger from the north west province of South Africa. Toxicol Rep, 6, 489-495 (2019)

Park JW, Yoo MS, Kuk JH, Ji YA, Lee JH. Simultaneous determination and monitoring of aflatoxin and ochratoxin
A in food. J Fd Hyg Safety, 28, 75-82 (2013)

Park M, Bae J, Lee DS. Antibacterial activity of [10]gingerol and [12]-gingerol isolated from ginger rhizome against periodontal bacteria. Phytother Res, 22, 14461449 (2008)

Pestka JJ. Deoxynivalenol: Mechanisms of action, human exposure, and toxicological relevance. Arch Toxicol, 84, 663-679 (2010)

Rural Development Administration. Agricultural Technology Guide 118: Barley. Registration Number: 11-1390000004507-14, p 41 (2018a)

Rural Development Administration. Agricultural Technology Guide 44: Wheat. Registration Number: 11-1390000004508-14, p 41 (2018b)

Rural Development Administration. Cultivation of Ginger. Registration Number: 11-1390000-001535-14, p 26 (2005)

Smith MC, Nadec S, Coton E, Hymery N. Natural cooccurrence of mycotoxins in foods and feeds and their in vitro combined toxicological effects. Toxins, 8, 94, 1-36 (2016)

Speijers GJA, Speijers MHM. Combined toxic effects of mycotoxins. Toxicol Lett, 153, 91-98 (2004)

Stoilova I, Krastanov A, Denev P, Gargova S. Antioxidant activity of a ginger extract (Zingiber officinale). Food Chem, 102, 764-770 (2007)

Tosun H, Arslan R. Determination of aflatoxin $B_{1}$ levels in organic spices and herbs. Sci World J, 2013, 1-4 (2013)

Trucksess MW, Weaver CM, Oles CJ, Rump LV, White $\mathrm{KD}$. Use of multitoxin immunoaffinity columns for determination of aflatoxins and ochratoxin $\mathrm{A}$ in ginseng and ginger. J AOAC Int, 90, 1042-1049 (2007)

Truksess M, Weaver C, Oles C, D’Ovidio K, Rader J. Determination of aflatoxins and ochratoxin $\mathrm{A}$ in ginseng and other botanical roots by immunoaffinity column cleanup and liquid chromatography with fluorescence detection. J AOAC Int, 89, 624-630 (2006)

Truksess MW, Weaver CM, Oles CJ, Fry Jr FS, Noonan GO, Betz JM, Rader JI. Determination of aflatoxins $B_{1}$, $B_{2}, G_{1}$, and $G_{2}$ and ochratoxin $A$ in ginseng and ginger by multitoxin immunoaffinity column cleanup and liquid chromatographic quantitation: Collaborative study. J AOAC Int, 91, 511-523 (2008)

United States Pharmacopeial Convention. USP Herbal Medicines Compendium. United States Pharmacopeial 
Convention, Rockville, MD, USA (2017)

Van der Merwe KJ, Steyn PS, Fourie L, Scott DB, Theron JJ. Ochratoxin A, a toxic metabolite produced by Aspergillus ochraceus Wilh. Nature, 205, 1112-1113 (1965)

Vesonder RF, Ellis JJ, Kwolek WF, DeMarini DJ. Production of vomitoxin on corn by Fusarium graminearum NRRL 5883 and Fusarium roseum NRRL 6101. Appl Environ Microbiol, 43, 967-970 (1982)

Wawrzyniak J, Ryniecki A, Gawrysiak-Witulska M. Kinetics of mould growth in the stored barley ecosystem contaminated with Aspergillus westerdijkiae, Penicillium viridicatum and Fusarium poae at $23-30^{\circ} \mathrm{C}$. J Sci Food Agric, 93, 895-901 (2013)

Wen J, Kong W, Wang J, Yang M. Simultaneous determination of four aflatoxins and ochratoxin $\mathrm{A}$ in ginger and related products by HPLC with fluorescence detection after immunoaffinity column clean-up and postcolumn photochemical derivatization. J Sep Sci, 36, 3709-3716 (2013)

Wen J, Kong W, Hu Y, Wang J, Yang M. Multi-mycotoxins analysis in ginger and related products by UHPLC-FLR detection and LC-MS/MS confirmation. Food Control,
43, 82-87 (2014)

Wu F. Perspective: Time to face the fungal threat. Nature, 516, S7 (2014)

Yang X, Gao J, Liu Q, Yang D. Co-occurrence of mycotoxins in maize and maize-derived food in China and estimation of dietary intake. Food Addit Contam Part B Surveill, 12, 124-134 (2019)

Yang Y, Wen J, Kong W, Liu Q, Luo H, Wang J, Yang M. Simultaneous determination of four aflatoxins and ochratoxin $\mathrm{A}$ in ginger after inoculation with fungi by ultra-fast liquid chromatography-tandem mass spectrometry. J Sci Food Agric, 96, 4160-4167 (2016)

Zhang Y, Pei F, Fang Y, Li P, Xia J, Sun L, Zou Y, Shen F. Interactions among fungal community, Fusarium mycotoxins, and components of harvested wheat under simulated storage. J Agric Food Chem, 67, 8411-8418 (2019)

Zinedine A, Brera C, Elakhdari S, Catano C, Debegnach F, Angelini S, De Santis B, Faid M, Benlemlih M, Minardi $\mathrm{V}$, Miraglia M. Natural occurrence of mycotoxins in cereals and spices commercialized in Morocco. Food Control, 17, 868-874 (2006) 